\title{
Land Use Transitions and Farm Performance in China: A Perspective of Land Fragmentation
}

\author{
Shukun Wang, Dengwang Li *, Tingting Li and Changquan Liu \\ Rural Development Institute, Chinese Academy of Social Sciences, Beijing 100732, China; \\ wangshukun@cass.org.cn (S.W.); litt@cass.org.cn (T.L.); liuchq@cass.org.cn (C.L.) \\ * Correspondence: lidw@cass.org.cn
}

Citation: Wang, S.; Li, D.; Li, T.; Liu, C. Land Use Transitions and Farm Performance in China: A Perspective of Land Fragmentation. Land 2021, 10, 792. https://doi.org/10.3390/ land10080792

Academic Editors: Hualou Long, Xiangbin Kong, Shougeng $\mathrm{Hu}$, Yurui Li and Elisa Marraccini

Received: 8 May 2021

Accepted: 24 July 2021

Published: 28 July 2021

Publisher's Note: MDPI stays neutral with regard to jurisdictional claims in published maps and institutional affiliations.

Copyright: (c) 2021 by the authors. Licensee MDPI, Basel, Switzerland. This article is an open access article distributed under the terms and conditions of the Creative Commons Attribution (CC BY) license (https:// creativecommons.org/licenses/by/ $4.0 /)$.

\begin{abstract}
Land fragmentation (LF) is widespread worldwide and affects farmers' decision-making and, thus, farm performance. We used detailed household survey data at the crop level from ten provinces in China to construct four LF indicators and six farm performance indicators. We ran a set of regression models using OLS methods to analyse the relationship between LF and farm performance. The results showed that (1) LF increased the input of production material and labour costs; (2) LF reduced farmers' purchasing of mechanical services and the efficiency of ploughing; and (3) LF may increase technical efficiency (this result, however, was not sufficiently robust and had no effect on yield). Generally speaking, LF was negatively related to farm performance. To improve farm performance, it is recommended that decision-makers speed up land transfer and land consolidation, stabilise land property rights, establish land-transfer intermediary organisations and promote large-scale production.
\end{abstract}

Keywords: land fragmentation; farm performance; land transfer; China

\section{Introduction}

Over the past four decades, China's agriculture productivity has improved significantly [1], with a real growth rate of $6.1 \%$ in the Gross Value of Agricultural Output (GVAO) per year throughout 1978-2015 [2]. With the economic development of urban and rural areas, China's land use has also undergone a transition. Agricultural arable land from land fragmentation to large-scale management is regarded as an essential transition path. Since the late 1980s, the Chinese Government began consciously encouraging land consolidation and promoting land transfer between rural households, as many rural labourers began to enter the cities for employment [3-5]. With the government's firm policy of support, the land rental market has experienced rapid development. According to Ministry of Agriculture data, the total rental area of arable land in China was 0.6 million hectares in 1994 and exceeded 35.9 million hectares in 2018, with an average increase of $18.6 \%$. According to the third national agricultural census results, the proportion of large-scale farming (more than 3.33 hectares in China's southern provinces and more than 6.67 hectares in its northern provinces) across the total arable land area reached $28.6 \%$ in 2016.

In recent years, China's land transfer rate has slowed [6]. One of the main reasons for this is severe land fragmentation (LF). LF is a typical characteristic of China's traditional agriculture. The status quo of LF in China can be traced back to the very beginning of rural reform in the late 1970s when the Household Responsibility System (HRS) had just been introduced. The HRS reallocated collective agricultural land to individual rural households equally, giving them relative autonomy over land-use decisions and crop selection. Due to differences in fertility and topography, the arable land was divided into different grades, and each household was assigned several plots of different land quality $[7,8]$. In some areas, farmers obtained as many as dozens of plots. Although this land allocation method guaranteed fairness and justice among rural households, it was extremely inconvenient in terms of agricultural production. 
Generally speaking, LF affects farmers' production decisions and, thus, their farm performance. Most scholars and policymakers believe LF decreases farm performance due to an inability to achieve an economy of scale. Additionally, LF simultaneously increases the area taken up by ridges, ditches, and roads between plots, wasting arable land resources. As the plots are scattered, the irrigation and mechanical efficiency of the cultivated land is significantly reduced $[9,10]$. When farmers want to operate on a large scale, large numbers of plots need to be transferred, in turn increasing land transaction costs [11]. Further, some people propose that land fragmentation increases the input cost of fertilisers and pesticides [12,13], reducing the rural labour emigration [14] while also reducing yields and household income [15-18]. Due to a series of negative effects induced by LF, many scholars believe that land transfer [19] and consolidation [20] should be accelerated to promote large-scale land production.

Some scholars believe that LF has a positive impact on farm performance. Those who support this view believe farmers can adjust their planting structure according to the characteristics of different plots to alleviate the lack of seasonal supply of rural labour, especially in traditional agriculture, which can profit from intensive cultivation [21,22]. According to different plots, LF allows farmers to allocate production factors to increase land productivity and food diversification, acceptability, accessibility, and sovereignty at the local level $[23,24]$. At the same time, a variety of crops can be planted to reduce market risks and farmers' exposure to weather variability $[25,26]$. LF can also speed up the transfer of rural labour out of agriculture [16].

Even if the same indicators are selected, research findings differ across countries. For example, Tan et al. [27] adopted China's farm household survey data and found that the number of plots had a positive impact on technical efficiency. In contrast, Rahman and Rahman [17] used the same indicators and methods on farmers' survey data in Bangladesh and found that LF decreased technical efficiency. The research mentioned above focused primarily on a single farm performance indicator, and few scholars have systematically analysed multiple indexes of LF on farm performance. Only Latruffe and Piet [28] used data from Brittany, France, to analyse the impact of LF on 15 farm performance indicators. Comparatively, China has more people, less land per capita than France, and land fragmentation has become more serious. Several studies have investigated the impact of LF on agriculture production in China, including its effect on technical efficiency [27], product costs [29], and returns relative to scale [30,31]. However, these studies have two main deficiencies: (1) the study sites were concentrated in one area, and (2) the sample sizes were small. Few studies have comprehensively examined the relationship between LF and multiple farm performance indicators in China.

This paper used crop-level data from ten provinces in China to determine the relationship between LF and multiple production indicators to identify the advantages and/or disadvantages of LF on farm performance. To achieve this goal, we selected four LF indicators and six farm performance indicators, giving a total of 24 regression models, using the unique large-scale survey data in China. With this, we empirically analysed the relationship between LF and farm performance. The findings of the current research address a gap in the existing literature and have essential reference significance for land policy recommendations.

The remainder of this paper is structured as follows. Section 2 provides a literature review. Section 3 outlines the methods used in the study, including data collection, indicator selection, model specification, and variable selection. Section 4 reports the empirical results and discusses the data. Section 5 presented the robustness test. Finally, Section 6 presents the study's conclusions and policy implications.

\section{Land Reform and Literature Review}

\subsection{An Overview of Land Reform in China}

In China, the land is owned by the State or village collectives. According to China's constitution and Land Administration Law, land in urban areas is owned by the State, 
while the State expropriates rural land except for that owned by the collectives, which means that the village or group effectively owns it. Before the Household Responsibility System (HRS) was introduced, rural land was owned by collectives and jointly utilised by their members-that is, agricultural operations were organised at the collective level. This, however, was widely regarded as inefficient [31].

The HRS reform began in the late 1970s, assigned collective agricultural land to individual rural households in an equalitarian way with contracts of up to 15 years, and entitled them to relative autonomy over land-use decisions and crop selection. Due to China's limited land resources, land quality varies greatly, even within the same village. To ensure an even distribution, the land is generally divided into three grades (i.e., good, medium, and poor), and these three land types are equally distributed according to the number of people in each household. Although this method of allocating land accords fairness and justice to farmers, it results in a farmer owning multiple plots, with the land parcels often far apart. These strategies led to land fragmentation among Chinese farmers.

For a long time following the introduction of HRS, although the land-use right of rural land belonged to farmers, the circulation of the right among farmers was not legitimate. Facing a growing voice of legalising the land rental market in the context of rapid urbanisation and with rural labourers flooding cities to work in China, the government revised the Rural Land Contract Law. Under the usufruct right, the renting out and mortgaging of rural land is now permitted. Nowadays, as the rural labour force in China continues to decrease and agricultural mechanisation increases, the Chinese Government is encouraging farmers to transfer land and expand their scale of planting.

\subsection{Literature Review}

To conduct an extensive literature search, a keyword search was initially conducted on specific literature databases such as Google Scholar, Web of Science, the Web of Knowledge, Research in Agricultural \& Applied Economics (AgEcon-Search) and others. Keywords such as "Land fragmentation", "LF", "agriculture production" (and combinations of these) were used. The indicators of LF and farm performance, and the relationship between them, are presented in Table 1.

One stream of previous research has discussed the concept and measurement methods of LF, building the foundation for further research. Two broad viewpoints can be distinguished concerning LF measurement, namely single indicator methods and comprehensive index methods. The former treats LF as one or several indicators, such as plot number, the average area of each plot [21,32-34], the ratio of plot number to farm size, and the time spent for all parcels [35]. The comprehensive index methods combine all single indicators to generate a comprehensive index. The three most commonly used indicators include Januszewski's Index, Simpson's Index, and Igbozurike's Index [36-38].

Another consideration that previous studies have investigated is the effect of LF on agriculture production and farm performance. The vast majority of studies suggest that LF is not conducive to farm performance. One factor is the impact of land fragmentation on production costs. Kawasaki [12] used data from rice farmers in Japan to calculate costs using the stochastic frontier method based on a C-D production function and translog production function, revealing that the impact of land plot number on cost was negative. Specifically, the decrease in agricultural productivity led to the transfer of labour to nonagricultural sectors. The second is the impact of land fragmentation on income. Based on household survey data from Vietnam, Tran et al. [18] used the Simpson's Index to measure land fragmentation, concluding that land fragmentation significantly reduced household income after overcoming endogeneity. The other factor is the effect on productivity. Based on household survey data, both Looga et al. [37] and Rahman et al. [17] concluded that LF decreases yield. Most of the abovementioned studies focus on analysing a single production performance measure, and few scholars have used the same set of data to study the impact of LF on multiple production performance indicators. 
Arguably, the current controversy involves the impact of LF on technical efficiency. This area of the current research mainly involves the use of the stochastic frontier method or the DEA method to first calculate the technical efficiency and then evaluate the impact of LF on technical efficiency through the use of the OLS method. Most scholars believe that land fragmentation has a negative impact on productivity. For example, Latruffe et al. [28] used French farm household survey data and adopted the OLS method to find that land fragmentation decreased total factor productivity and technical efficiency. However, some scholars have found a positive impact. Tan et al. [27] believe that LF enables farmers to more effectively allocate input elements and improve technical efficiency. Ciaian et al. [34] believe that in areas where rural labour is surplus, land fragmentation can make full use of agricultural labour and improve technical efficiency.

Table 1. Literature review on LF, farm performance, and their relationship.

\begin{tabular}{|c|c|c|c|c|}
\hline Author and Year & LF Indictor & $\begin{array}{l}\text { Farm Performance } \\
\text { Indictor }\end{array}$ & Country & Relationship \\
\hline \multicolumn{5}{|c|}{ Panel A: LF has a "bad" relationship with performance } \\
\hline Jabarin et al. (1994) [39] & Whether farmers located in production region & Production cost & Jordan & + \\
\hline Kawasaki et al. (2010) [12] & The number of plots per farm household & Production cost & Japan & + \\
\hline Tan et al. (2010) [27] & Average distance of the plots to the homestead & Technical efficiency & China & - \\
\hline Austin et al. (2012) [40] & Januszewski Index & $\begin{array}{l}\text { Value of farm output to } \\
\text { the value of inputs per } \\
\text { hectare }\end{array}$ & Nigeria & - \\
\hline Jia et al. (2014) [41] & The number of plots per farm household & $\begin{array}{l}\text { Marginal productivity of } \\
\text { labour }\end{array}$ & China & - \\
\hline Latruffe et al. (2014) [28] & The number of plots per farm household & Technical efficiency & France & - \\
\hline Alemu et al. (2017) [42] & $\begin{array}{l}\text { Average distance of parcels from homestead; } \\
\text { cultivated parcel number }\end{array}$ & Yields & Ethiopia & - \\
\hline Tran et al. (2019) [18] & Simpson's Index & $\begin{array}{l}\text { Per capita household } \\
\text { income }\end{array}$ & Vietnam & - \\
\hline Lu et al. (2019) [15] & The number of plots per farm household & $\begin{array}{l}\text { Marginal productivity of } \\
\text { labour }\end{array}$ & China & - \\
\hline Lu, Xie et al. (2018) [31] & Simpson's Index & Scale elasticity & China & - \\
\hline $\operatorname{Tan}(2005)[43]$ & Average distance of the plots to the homestead & Production cost & China & + \\
\hline He (2014) [29] & Simpson's Index & Production cost & China & + \\
\hline Wan et al. (2001) [30] & The number of plots per farm household & Scale elasticity & China & - \\
\hline \multicolumn{5}{|c|}{ Panel B: LF has a "good" relationship with performance } \\
\hline Tan et al. (2010) [27] & The number of plots, average plot size & Technical efficiency & China & $+/+$ \\
\hline Ciaian et al. (2018) [34] & The number of plots per farm household & Technical efficiency & Albania & + \\
\hline Kadigi et al. (2017) [44] & $\begin{array}{l}\text { The size and number of parcels; average } \\
\text { distance to parcels; the Simpson Index }\end{array}$ & Yield & Tanzania & + \\
\hline Veljanoska (2018) [45] & $\begin{array}{l}\text { Number of plots; number of plots with } \\
\text { different soil texture; number of plots with } \\
\text { different slope; Simpson's Index }\end{array}$ & $\begin{array}{l}\text { Adapting to climate } \\
\text { change }\end{array}$ & Uganda & + \\
\hline Knippenberg et al. (2020) [22] & Number of plots; Simpson's Index & Food security & Ethiopia & + \\
\hline Looga et al. (2018) [37] & $\begin{array}{l}\text { Schmook Index; Januszewski Index; average } \\
\text { size of the parcel; number of parcels; } \\
\text { area-weighted mean size of the parcels; total } \\
\text { area of landholding }\end{array}$ & $\begin{array}{l}\text { Productivity per working } \\
\text { hour and net value added } \\
\text { per working hour }\end{array}$ & Estonia & U-shape \\
\hline
\end{tabular}

Source: The conclusions outlined above were derived from the author's review of the literature presented in the current study.

\section{Methodology}

\subsection{Data}

The data used in this study were collected from a rural household survey organised by the Rural Development Institute of the Chinese Academy of Social Sciences in 2020. The total sample size of the survey was 3833 farmer households from ten major agricultural production provinces in China. The surveying involved stratified random sampling in selecting the sample provinces, counties, villages, and rural households to be used in the study. First, ten provinces, including Heilongjiang province in the northeast, Zhejiang, Shandong, and Guangdong in the east, Anhui and Henan in the central region, and Guizhou, Sichuan, Shaanxi, and Ningxia in the west, were selected based on the level of provincial economic development. Second, within each province, the survey categorised 
all counties into five groups (i.e., high, relatively high, middle, relatively low, and low) according to their per capita GDP, and then randomly selected one county from each group. Next, the survey randomly selected three towns from each county and two villages from each town. Finally, 12-14 rural households in each village were randomly selected. Of the total 3833 sampled households, $64 \%$ were engaged in agricultural production. Of the households engaged in agricultural production, $30.90 \%$ and $41.67 \%$ planted one and two kinds of crops, respectively. The distribution structure of the survey area is shown in Figure 1.

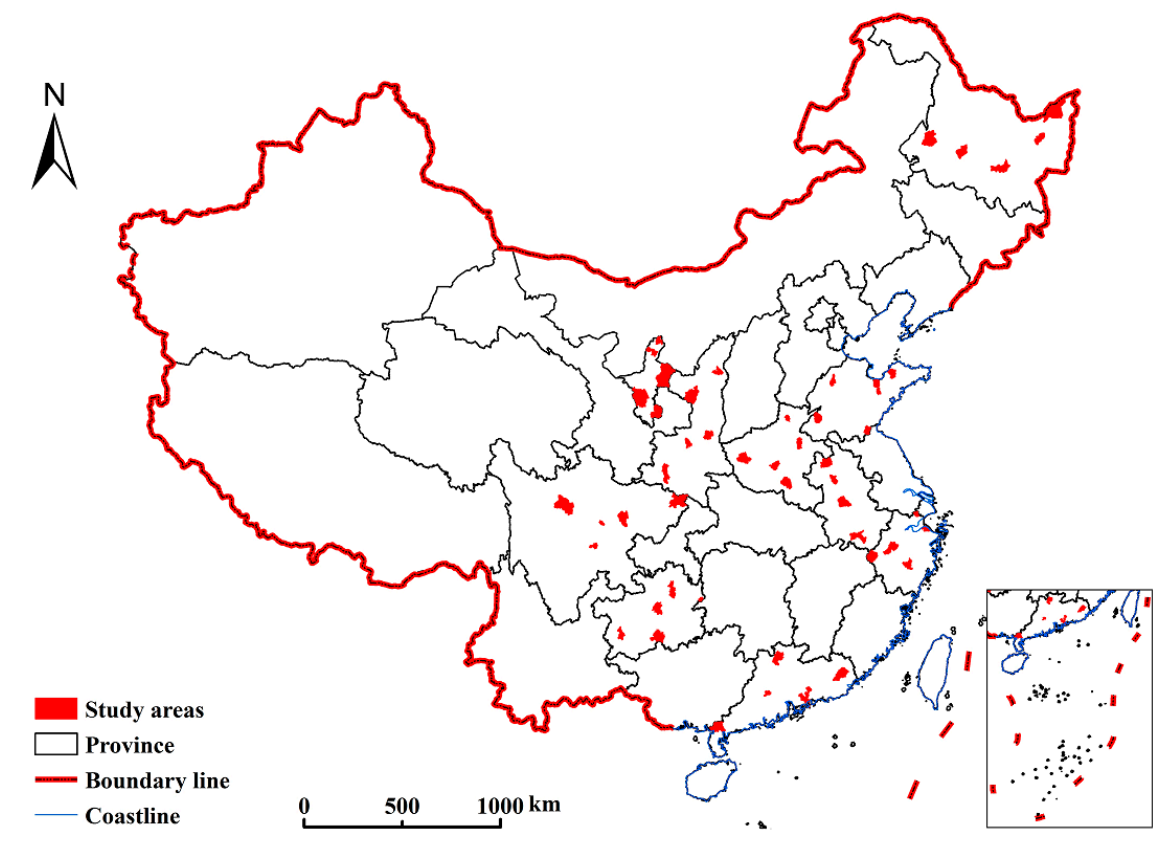

Figure 1. Distribution of household survey sites.

The surveys collected information at the village, household, and crop levels. At the household level, the data contain the following information: (1) detailed information about household agricultural production, including the output and input of each crop; (2) plotlevel information, including the number of plots, the area of the largest three plots, and the average distance of the largest three plots from the household residence; (3) household characteristics, such as family size, the structure of the family labour force, and family members' age and education level. The survey data contains general information on the village population and geographical information about land at the village level.

In China, it is common for farmers to produce various crops within a year for two main reasons; the first is diversified planting. Specifically, to avoid natural and market risks, farmers may plant multiple crops simultaneously. The second is, planting two or three seasons worth of crops in a year. This situation is more common in North and South China, compared to Western and Northeastern region. For example, corn is planted after wheat is harvested in North China, and rapeseed is planted after the rice is harvested in the country's southern provinces. In the study sample, $69 \%$ of farmers planted more than one crop in one year. Therefore, we selected crop-level data for empirical analysis. In the survey, we asked for information on common crops with a total area of more than $0.5 \mathrm{mu}$ per household. These mainly included wheat, rice, corn, soybeans, rapeseed and silage maize.

\subsection{Measuring Farm Performance and Land Fragmentation}

\subsubsection{Farm Performance}

A series of indicators were selected to reflect farm performance, and these were divided into three categories. The first category is cost-benefits for farmers, and two 
indicators were included: (1) materials cost usage (i.e., the total of material costs per mu of pesticides, fertilisers, seeds, and irrigation for each crop); and (2) labour cost usage (i.e., the total of the labour costs and the opportunity cost of their own labour-here, the average price of hired labour in the village was used to estimate the opportunity cost of their own labour).

The second category is the use of mechanisation by farmers, in which two indicators were used: (1) the total input of mechanised services purchased in different production stages of each crop, including ploughing, sowing, spraying, fertilising, irrigation, harvesting, and other production processes; and (2) the efficiency of mechanical ploughing for each crop. During the survey, if the farmer used mechanical ploughing, we asked farmers to answer the scale of ploughed land per hour for different crops, and we used this indicator to measure the efficiency of ploughed land.

The third category is productivity, in which two indicators of yield and technical efficiency were used. Yield constitutes the average output per mu of different crops (as answered by the farmers) and technical efficiency. Technical efficiency constitutes the effectiveness with which a given set of inputs were used to produce an output. In general, technical efficiency can be calculated in two ways: (1) using the parametric stochastic frontier analysis (SFA) approach, or (2) using non-parametric data envelopment analysis (DEA). Based on the research by Ciaian et al. [34] and Belotti et al. [46], the SFA approach was adopted for the current study. The model is described in detail in Section 3.3.

\subsubsection{Land Fragmentation}

From Table 1, the current research indictors of LF are the Simpson's Index [18,22,29], Januszewski Index $[37,40]$, number of plots $[12,28,41]$, average plot size $[37,44]$, and average distance from plot to home $[10,27,42]$ (among others). The Simpson and Januszewski indexes are considered ideal indicators because they simultaneously reflect the number of plots, plot size, and total scale, which can be defined as SI $=1-\sum_{a=1}^{n} \mathrm{a}_{i}^{2} / \sum_{a=1}^{n} \mathrm{a}_{i}$ and $\mathrm{JI}=\sqrt{\sum_{a=1}^{n} a_{i}} / \sum_{a=1}^{n} \sqrt{a_{i}}$, where $a_{i}$ is the size of the plot $i$. At the same time, because the calculation of the abovementioned two indexes requires the size of each piece of land, it is difficult to obtain data from some countries where the land is fragmented. Most scholars use multiple indicators to measure LF, including the number of plots, the average plot size, and the average distance from the plot to home (Table 1). We investigated the number of plots on each crop, the sown area of each crop, the area of the largest three plots, and the average distance of the largest three plots to home on a farmer's planting of more than $0.5 \mathrm{mu}$ of cereals crops. We selected three indicators to represent LF at the crop level from different farmers. The number of plots constitutes the first LF indicator used at the crop level; the second indicator is the proportion of the area of the largest three plots to the total area; the third indicator is the average distance from the largest three plots to farmers homes, and the fourth indicator is the average plot size. The largest three pieces of land can be used to measure the concentration of farmers' farmland. In the absence of the size and distance of each piece, we believe that the proportion of the largest three pieces of land to the total area and the average distance from the largest three pieces of land can also be used to measure the fragmentation of farmers' land.

\subsection{Empirical Specification}

The model specification is composed of two main parts. The first part calculates the indicators of farm performance, and the second calculates the impact of LF on farm performance. The survey of farmers directly supplied some indicators of farm performance-for example, yields and ploughing efficiency-while some indicators were obtained through simple calculations-for example, the material cost is the sum of chemical fertilisers, pesticides and seed costs. After obtaining the above indicators, the OLS model was used to measure the impact of LF on a series of indicators representing farm performance. We used four LF indicators and six indicators of farm performance, giving 24 regression models. The relevant model is detailed below. 
(1) OLS estimation model

$$
Y_{h i k}=\beta_{0}+\beta_{1} L F_{h i f}+\beta_{2} C_{h i}+\beta_{3} F_{h}+\beta_{4} H_{h}+I_{i}+D_{d}+\varepsilon_{h i}
$$

Based on findings from previous studies [22,28], we used the OLS model to estimate a series of farm performance indicators in addition to technical efficiency (see model [1]). $Y_{h i k}$ represents the $k$-th farm performance indicator of the $h$-th farmer, planting the $i$-th crop (where $i$ represents the six crops of wheat, corn, rice, soybean, rapeseed, and silage corn), and $L F_{h i f}$ constitutes the key variable in the model, which represented the $f$-th $L F$ index of the $h$-th farmer planting the $i$-th crop. Further, $C_{h i}$ represents the control variables at the crop level, such as disaster damage, irrigation conditions. and sown area; $F_{h}$ represents the control variables at the household level, which represents the family size and whether there were non-agricultural workers in the $h$-th farmer's household; and $H_{h}$ represents the control variables at the household-head level, including the gender of the household head, education level, and whether he or she was a village cadre ('Village cadre' mainly refers to the management personnel in the village, which mainly includes the village leader, village director, and accountant). $I_{i}$ and $D_{d}$ denote crop and regional control variables (including the eastern, central, western, and northeastern regions of China), respectively. Finally, $\varepsilon_{h i}$ represents the error term.

\section{(2) Technical efficiency estimation model}

A stochastic production frontier (SFA) model was used to estimate the effect of LF on technical efficiency. Many researchers have often incorporated exogenous effects using a two-step approach. The first step is to use the production function to estimate technical inefficiency, and the second is to use the regression method to estimate the impact of some factors on technical inefficiency. As pointed out by Wang and Schmidt [46] and Belotti et al. [47], this approach leads to severely biased results; thus, we focused only on model extensions based on simultaneous estimation. The model settings are shown in Formulas (2)-(4):

$$
\begin{gathered}
\ln Y_{h i}=\beta_{0}+\sum_{j=1}^{4} \beta_{j} \ln X_{h i j}+\frac{1}{2} \sum_{j=1}^{4} \sum_{k=1}^{4} \beta_{h j k} \ln X_{h i j} \ln X_{h i k}+v_{h i}-\mu_{h i} \\
\mu_{h i}=N^{+}\left(\mu_{h i}, \sigma_{u}^{2}\right) \\
\mu_{h i}=z_{h i}^{\prime} \varphi
\end{gathered}
$$

In the formulas outlined above, subscript $h$ represents the household, subscript $i$ represents different crops, and subscript $j$ represents different input variables. Therefore, $\ln$ $Y_{h i}$ in Equation (2) is the logarithm of yield on crop $i$ of farmer $h$, including wheat rice, maise, soybean, rapeseed and silage maise. $X_{h i j}$ represents the material costs (e.g., fertilisers, seeds, and irrigation), labour costs, mechanical service costs, and land costs for the $i$ th crop of farmer $h$. The term $u_{h i}$ specified in Equation (2) is the log difference between the maximum and actual output; and $u_{h i}$ is a realisation from an exponential distribution variable; $z_{i}$ is a vector of the exogenous variables; and $\varphi$ is the vector of unknown parameters to be estimated (the so-called inefficiency effects). In model (4), the $z_{h i}$ represents different LF indicators. STATA16 was used to estimate the models given above.

Notably, the abovementioned models may have endogenous problems-for example, the impact of LF on yield. Farmers with severe LF may have low agricultural production technology and management capabilities, leading to biased estimation results. Generally speaking, instrumental variables are used to solve the problem. For example, Wang et al. [10] used geographic dummy variables as instrumental variables for LF to study the impact of LF on income. The current study selected six indicators to measure farm performance. It was difficult in the current study to address the endogeneity of each indicator, as this cannot easily be done within the scope of a single study. Research by Latruffe et al. [28] and Ciaian et al. [34] predominantly used the OLS method to explore 
the correlation between China's LF and farm performance from multiple dimensions. Although causality cannot be inferred in the current study, we believe our findings have important reference significance for academic research and policymaking.

\subsection{Description of Variables}

Table 2 is a descriptive statistical analysis of all variables, predominantly reporting the mean, standard deviation, minimum, and maximum values. The table shows that the average number of plots at the crop level was 3.6, and the number of plots varied greatly, with a maximum value of 21 and a minimum value of 1 . The average proportion of the largest three plots of land to the total sown area was 0.85 , which is relatively concentrated. The largest three land plots were $0.95 \mathrm{~km}$ away from the farmers' homes, which was generally close to home and ranged between 0 and $9 \mathrm{~km}$. Those farmers land that was $0 \mathrm{~km}$ from the household were mainly farming arable land next to their yard. The average plot size was $3.87 \mathrm{mu}$. In the following model, the four indicators representing LF are expressed by LF1, LF2, LF3 and LF4, respectively.

In terms of the farm performance indicators, the average material cost input of chemical fertilisers, seeds, pesticides, and irrigation was found to be 277.16 yuan per mu. The average yield of six crops was $417 \mathrm{~kg}$ per mu. Labour input costs mainly included the sum of farmers' labour opportunity costs and employment labour costs, with an average of 259.59 yuan per mu. The average purchase of mechanised services for the whole crop growth process was found to be 97.67 yuan per $\mathrm{mu}$, including tilling land, fertilisation, sowing, harvesting, and other links. This index fluctuated greatly, and the minimum value of 0 indicates that manual or animal labour was used during crop production. The efficiency of mechanised ploughing was $3.27 \mathrm{mu}$ per hour, which varied greatly, with the ploughed area ranging from $0.2 \mathrm{mu}$ to $17.3 \mathrm{mu}$ per hour. We defined the total income minus the material cost input as the profitability indicator, and the average profitability of the crop was found to be 476.85 yuan per mu.

Various control variables were chosen based on the household decision-making model, and findings from previous studies were used in all 18 regressions. The average resident population per household was 3.28, the average sowing area per household was $18.43 \mathrm{mu}$, $66 \%$ of the crops were not affected by natural disasters, and $53 \%$ of the farmers did not take out agricultural insurance. Household heads were predominantly male, and their education level was mainly at the primary and junior high school level, accounting for $79 \%$ of the total. Village cadres were $18 \%$ of household heads, and only $5 \%$ of the people were engaged in non-agricultural work. In the sample, the percentages of wheat, rice, corn, soybean, rapeseed, and silage corn were $23 \%, 19 \%, 47 \%, 5 \%, 3 \%$, and $4 \%$, respectively.

A specific correlation between farm size and productivity was found. Most studies have concluded there is an inverse relationship between farm size and agriculture productivity [48-50], even though several scholars have reported a U-shaped relationship [51]. Under this assumption, if there is a correlation between land fragmentation and farm size, a confounding effect in which farmers are allocating inputs due to farm size rather than LF can be considered. Figure 2 shows the data depicts a positive correlation between farm size and LF. Therefore, it was necessary to control the variable of farm size in the regression model, and this estimated result was considered together with the LF variable. 
Table 2. Descriptive statistics and variable definitions.

\begin{tabular}{|c|c|c|c|c|c|}
\hline Variable & Definition or Unit & Mean & Std. Dev. & Min. & Max. \\
\hline \multicolumn{6}{|c|}{ Land Fragmentation Indicator } \\
\hline LF1 & Number of plots & 3.63 & 3.06 & 1 & 21 \\
\hline LF2 & $\begin{array}{l}\text { The proportion of the largest three plots of land to the total } \\
\text { crop area. }\end{array}$ & 0.85 & 0.23 & 0 & 1 \\
\hline LF3 & The average distance of the three largest plots from home $(\mathrm{km})$ & 0.95 & 0.93 & 0 & 9 \\
\hline LF4 & Average plot size & 3.87 & 7.24 & 0.03 & 78 \\
\hline \multicolumn{6}{|c|}{ Farm Performance Indicator } \\
\hline Material cost & Included fertiliser, seed, pesticide, and irrigation cost (yuan/mu) & 277.16 & 151.46 & 14.1 & 2660 \\
\hline Yield & $\mathrm{Kg} / \mathrm{mu}$ & 417 & 182.16 & 2 & 1000 \\
\hline Labour cost & $\begin{array}{c}\text { Including the cost of employment and the opportunity cost of own } \\
\text { labour (Yuan/mu) }\end{array}$ & 259.59 & 341.15 & 2 & 2480 \\
\hline $\begin{array}{l}\text { Purchase machinery } \\
\text { service }\end{array}$ & $\begin{array}{l}\text { Including ploughing land, fertilisation, sowing, harvest, and other } \\
\text { processes (Yuan/mu) }\end{array}$ & 97.67 & 90.69 & 0 & 520 \\
\hline Tilling efficiency & Mechanical arable area per hour $(\mathrm{Mu} /$ hour $)$ & 3.27 & 3.35 & 0.2 & 17.3 \\
\hline Profitability & Revenue minus material costs without farm subsidies (Yuan/mu) & 476.85 & 383.31 & -657.5 & 1832 \\
\hline \multicolumn{6}{|c|}{ Control Variables } \\
\hline \multicolumn{6}{|c|}{ Head of household characteristics } \\
\hline Gender & $1=$ female; $0=$ male & 0.04 & 0.2 & 0 & 1 \\
\hline \multicolumn{6}{|l|}{ Education level } \\
\hline illiteracy & $1=$ yes; $0=$ other & 0.07 & 0.26 & 0 & 1 \\
\hline$<=$ Primary school & $1=$ yes; $0=$ other & 0.3 & 0.46 & 0 & 1 \\
\hline Junior high school & $1=$ yes; $0=$ other & 0.49 & 0.5 & 0 & 1 \\
\hline Senior high school & $1=$ yes $; 0=$ other & 0.12 & 0.33 & 0 & 1 \\
\hline$>=$ College & $1=$ yes $; 0=$ other & 0.11 & 0.11 & 0 & 1 \\
\hline Village cadre & $1=$ yes; $0=$ other & 0.18 & 0.38 & 0 & 1 \\
\hline $\begin{array}{c}\text { Non-agricultural } \\
\text { employment }\end{array}$ & $1=$ yes; $0=$ other & 0.05 & 0.22 & 0 & 1 \\
\hline \multicolumn{6}{|c|}{ Household characteristics } \\
\hline Household size & Total number of permanent family members & 3.28 & 1.45 & 1 & 10 \\
\hline \multicolumn{6}{|c|}{ Crop characteristics } \\
\hline Farm size & $\mathrm{Mu}$ & 18.43 & 73.22 & 0.1 & 2200 \\
\hline Disaster & $1=$ The crop has not suffered natural disasters & 0.66 & 0.47 & 0 & 1 \\
\hline Insurance & $1=$ The crop is insured & 0.53 & 0.5 & 0 & 1 \\
\hline Land rent & Yuan $/ \mathrm{mu}$ & 516.2 & 319.5 & 30 & 2342 \\
\hline Crop & & & & & \\
\hline wheat & $1=$ yes $; 0=$ other & 0.23 & 0.42 & 0 & 1 \\
\hline rice & $1=$ yes $; 0=$ other & 0.19 & 0.4 & 0 & 1 \\
\hline maize & $1=$ yes $; 0=$ other & 0.47 & 0.5 & 0 & 1 \\
\hline soybean & $1=$ yes; $0=$ other & 0.05 & 0.21 & 0 & 1 \\
\hline rapeseed & $1=$ yes; $0=$ other & 0.03 & 0.18 & 0 & 1 \\
\hline silage maize & $1=$ yes $; 0=$ other & 0.04 & 0.19 & 0 & 1 \\
\hline
\end{tabular}

Note: Data from author survey; $1 \mathrm{Mu}=1 / 15 \mathrm{Ha}$; Yuan is the currency of China (1 USD = 6.90 Yuan in 2019).

In the literature, many studies have reported measurement errors on farm size based on the use of self-reported data [52,53]. However, this is not the case in China, since household farms hold better knowledge of the land areas in operation. The Ministry of Agriculture and Rural Affairs of China began conducting a large-scale land titling pilot in 2009. According to the investigation, code of practice for the right to rural contractual management (which the government developed), farmland details, including location, area, and owner of use rights, are being investigated in this pilot with the help of GPS/GNSS and drones. The results of the land titling pilot will officially be announced in the village for several days, and the farmers must confirm the outcomes. Then, the government will grant land certificates to the farmers. By the end of 2020, approximately $96 \%$ of the land in China was contractual. Therefore, we believe that the sample of farmers in the current study self-reported the details of their farmland with few errors. While collecting the data from the farmers in the sample, their land certificates and land rental contracts were also inspected. 

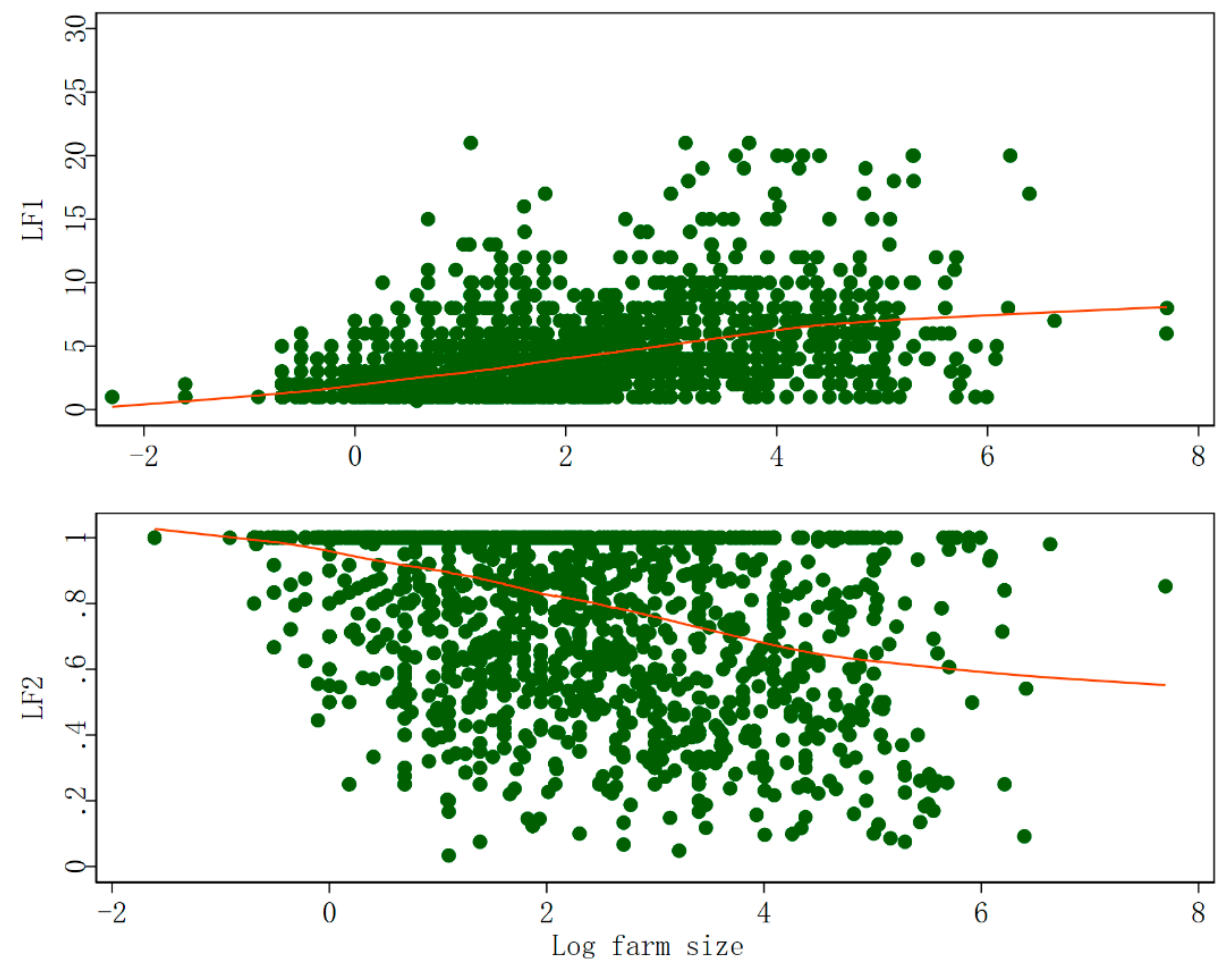

Figure 2. Relationship between farm size and land fragmentation (Bandwidth $=0.8$ ).

\section{Results and Discussion}

\subsection{The Results of LF on the Costs and Benefits}

\subsubsection{The Influence of LF on Material Cost}

The natural logarithm of the per mu material cost was used as the dependent variable to reduce the skewness distributions within the data. In Table 3, models (1)-(4) represent the relationships between the number of plots, the proportion of the largest three plots, the average distance of the largest three plots to home, average plot size and farmers' material costs at the crop level. The results generated from models (1)-(3) indicate that LF was associated with increased material cost, but the results from model (3) were slightly different. In model (1), after controlling for other variables, the number of plots was significantly positively related to material cost. The coefficient of the LF1 variable was 0.0192 , and this was statistically significant at the level of $1 \%$. As the number of plots increased, the material cost per mu increased by $1.92 \%$. Based on the average material cost of each crop of 277, each additional piece of a plot increased the average cost per mu by 5.32 Yuan. In model (2), it can be concluded that the proportion of the largest three plots of land and material costs were negatively correlated and statistically significant. In Model (3), LF was measured using the average distance of the largest three plots from home, showing that the further the average distance from home, the lower the material cost. When plots are further from home, farmers may reduce their material inputs, such as their use of pesticides and chemical fertilisers, due to the high costs associated with transportation and production. Although model (4) was not significant, it revealed that the larger the average plot was, the less material cost was input. The estimated result of model 3 diverged from Tan's [44] findings that the average distance from land to home revealed a positive relationship with material cost. However, Tan [44] used the average distance from all plots to a residence, and the survey data was collected from the Jiangxi Province, where land fragmentation is more severe. 
Table 3. Results of LF on production material cost.

\begin{tabular}{|c|c|c|c|c|}
\hline & Model (1) & Model (2) & Model (3) & Model (4) \\
\hline LF1 & $\begin{array}{l}0.0192^{* * *} \\
-5.057\end{array}$ & & & \\
\hline LF2 & & $\begin{array}{l}-0.0888^{*} \\
(-1.646)\end{array}$ & & \\
\hline LF3 & & & $\begin{array}{c}-0.0224^{* *} \\
(-1.975)\end{array}$ & \\
\hline LF4 & & & & $\begin{array}{l}-0.0006 \\
(-0.388)\end{array}$ \\
\hline Log farm size & $\begin{array}{c}-0.0796^{* * *} \\
(-6.561)\end{array}$ & $\begin{array}{c}-0.0576^{* * *} \\
(-5.174)\end{array}$ & $\begin{array}{c}-0.0465^{* * *} \\
(-4.643)\end{array}$ & $\begin{array}{l}-0.0541^{* * *} \\
(-4.905)\end{array}$ \\
\hline \multicolumn{5}{|l|}{ Head of household characteristics } \\
\hline Gender & $\begin{array}{l}0.0149 \\
-0.289\end{array}$ & $\begin{array}{l}0.0134 \\
-0.264\end{array}$ & $\begin{array}{l}-0.0017 \\
(-0.034)\end{array}$ & $\begin{array}{l}-0.0021 \\
(-0.041)\end{array}$ \\
\hline $\begin{array}{c}\text { Education level } \\
<=\text { Primary school }\end{array}$ & $\begin{array}{c}-0.0773 * * \\
(-1.973)\end{array}$ & $\begin{array}{l}-0.0764 * \\
(-1.920)\end{array}$ & $\begin{array}{l}-0.0627 \\
(-1.642)\end{array}$ & $\begin{array}{l}-0.0755^{*} \\
(-1.881)\end{array}$ \\
\hline Junior high school & $\begin{array}{l}-0.0318 \\
(-0.853)\end{array}$ & $\begin{array}{l}-0.0251 \\
(-0.665)\end{array}$ & $\begin{array}{l}-0.0213 \\
(-0.590)\end{array}$ & $\begin{array}{l}-0.0280 \\
(-0.733)\end{array}$ \\
\hline Senior high school & $\begin{array}{l}-0.0617 \\
(-1.383)\end{array}$ & $\begin{array}{l}-0.0625 \\
(-1.376)\end{array}$ & $\begin{array}{l}-0.0573 \\
(-1.295)\end{array}$ & $\begin{array}{l}-0.0612 \\
(-1.344)\end{array}$ \\
\hline$>=$ College & $\begin{array}{l}0.0317 \\
-0.265\end{array}$ & $\begin{array}{l}0.0364 \\
-0.304\end{array}$ & $\begin{array}{l}0.0479 \\
-0.404\end{array}$ & $\begin{array}{l}0.0356 \\
-0.297\end{array}$ \\
\hline Village cadre & $\begin{array}{l}-0.0082 \\
(-0.337)\end{array}$ & $\begin{array}{l}-0.0113 \\
(-0.460)\end{array}$ & $\begin{array}{l}-0.0078 \\
(-0.315)\end{array}$ & $\begin{array}{l}-0.0755^{*} \\
(-1.881)\end{array}$ \\
\hline Non-agricultural employment & $\begin{array}{l}0.0268 \\
-0.611\end{array}$ & $\begin{array}{l}0.0385 \\
-0.87\end{array}$ & $\begin{array}{l}0.0517 \\
-1.153\end{array}$ & $\begin{array}{l}0.0379 \\
-0.862\end{array}$ \\
\hline \multicolumn{5}{|l|}{ Family characteristics } \\
\hline Family members & $\begin{array}{l}0.0107 \\
-1.592\end{array}$ & $\begin{array}{l}0.0112 * \\
-1.654\end{array}$ & $\begin{array}{l}0.0138^{* *} \\
-2.018\end{array}$ & $\begin{array}{l}0.0128 * \\
-1.886\end{array}$ \\
\hline Disaster & $\begin{array}{c}-0.0528^{* *} \\
(-2.431)\end{array}$ & $\begin{array}{l}-0.0510 * * \\
(-2.344)\end{array}$ & $\begin{array}{c}-0.0481^{* *} \\
(-2.223)\end{array}$ & $\begin{array}{l}-0.0523 * * \\
(-2.402)\end{array}$ \\
\hline Insurance & $\begin{array}{l}-0.0252 \\
(-1.268)\end{array}$ & $\begin{array}{l}-0.0346^{*} \\
(-1.734)\end{array}$ & $\begin{array}{l}-0.0279 \\
(-1.400)\end{array}$ & $\begin{array}{l}-0.0357^{*} \\
(-1.782)\end{array}$ \\
\hline $\begin{array}{l}\text { Crop controls } \\
\text { Region controls }\end{array}$ & $\begin{array}{l}\text { yes } \\
\text { yes }\end{array}$ & $\begin{array}{l}\text { yes } \\
\text { yes }\end{array}$ & $\begin{array}{l}\text { yes } \\
\text { yes }\end{array}$ & $\begin{array}{l}\text { yes } \\
\text { yes }\end{array}$ \\
\hline Constant & $\begin{array}{l}5.5009 * * * \\
-61.06\end{array}$ & $\begin{array}{l}5.5803^{* * *} \\
-51.496\end{array}$ & $\begin{array}{l}5.4828^{* * *} \\
-61.425\end{array}$ & $\begin{array}{l}5.5027^{* * *} \\
-61.402\end{array}$ \\
\hline Observations & 2413 & 2405 & 2386 & 2427 \\
\hline R-squared & 0.19 & 0.184 & 0.178 & 0.179 \\
\hline
\end{tabular}

Note: Robust $t$-statistics in parentheses; ${ }^{* * *}$ significance at $1 \%$; ** significance at $5 \%$; ${ }^{*}$ significance at $10 \%$.

\subsubsection{The Influence of LF on Labour Input}

Similarly, we used the logarithm of labour input as a dependent variable. Table 4 shows the results of the effects of LF on the labour cost at the crop level. After controlling for other variables, through models (1) to (4), we can see that LF and labour input were positively related. However, model (4) did not reveal an obvious significant relationship. From model (1), each increase in the number of plots at the crop level increased the average labour force cost per mu by $5.46 \%$, and it was highly significant at the $1 \%$ level. Based on the average values of the sample, a saving of 14.17 Yuan for each additional plot could be made. The results of model (2) showed that when the proportion of the largest three plots increased by $1 \%$, the labour input decreased by 0.54 Yuan and was highly significant at the $1 \%$ level. The results of model (3) revealed that for every average increase of one $\mathrm{km}$ of the largest three plots, the labour input increased by $4.3 \%$, or 11.16 Yuan, according to the average value of the sample. In the survey, farmers were asked about the household labour input in each production stage, such as cultivated land, sowing, spraying insecticide, and harvesting, and then the opportunity cost based on the village-level labour employment 
price was calculated. This was then added to the hired labour input. Household labour input included preparation time and actual working time, with preparation time including the time taken to travel between the residence and the plot. It was determined that the further the farmer was from their residence, the more labour input cost he/she incurred. This finding is consistent with He's [29] findings derived from the use of the Simpson's Index.

Table 4. Results of LF on labour cost.

\begin{tabular}{|c|c|c|c|c|}
\hline & Model (1) & Model (2) & Model (3) & Model (4) \\
\hline LF1 & $\begin{array}{c}0.0546^{* * *} \\
-6.264\end{array}$ & & & \\
\hline LF2 & & $\begin{array}{c}-0.5421^{* * *} \\
(-5.269)\end{array}$ & & \\
\hline LF3 & & & $\begin{array}{c}0.0433 * \\
-1.902\end{array}$ & \\
\hline LF4 & & & & $\begin{array}{l}-0.0002 \\
(-0.048)\end{array}$ \\
\hline Log farm size & $\begin{array}{c}-0.4360 * * * \\
(-0.026)\end{array}$ & $\begin{array}{c}-0.3769 * * * \\
(-0.023)\end{array}$ & $\begin{array}{c}-0.3324^{* * *} \\
(-0.021)\end{array}$ & $\begin{array}{c}-0.3351^{* * *} \\
(-15.029)\end{array}$ \\
\hline Head of household characteristics controls & yes & yes & yes & yes \\
\hline Household characteristics controls & yes & yes & yes & yes \\
\hline Crop controls & yes & yes & yes & yes \\
\hline Region controls & yes & yes & yes & yes \\
\hline Constant & $\begin{array}{l}4.3286^{* * *} \\
-22.715\end{array}$ & $\begin{array}{c}4.7434^{* * *} \\
-21.233\end{array}$ & $\begin{array}{c}4.0605^{* * *} \\
-21.14\end{array}$ & $\begin{array}{l}4.1170 * * * \\
-21.926\end{array}$ \\
\hline Observations & 2523 & 2509 & 2489 & 2541 \\
\hline R-squared & 0.517 & 0.51 & 0.503 & 0.506 \\
\hline
\end{tabular}

Note: Robust $t$-statistics in parentheses; ${ }^{* *}$ significance at $1 \% ;{ }^{* *}$ significance at 5\%; ${ }^{*}$ significance at $10 \%$.

The analysis presented above shows that LF can significantly increase material and labour costs. Although the total cost of the reduction is small, it is meaningful in terms of proportion. Taking wheat production as an example, if material capital, labour cost, and land lease cost (including the opportunity of owning land) are deducted, the income per $\mathrm{mu}$ is only 51.6 Yuan (excluding subsidies). According to our regression results, under the condition of controlling the total sown area, each additional piece of land can increase the material cost for farmers by 5.32 Yuan and the labour cost by 14.17 Yuan, which accounts for $37.78 \%$ of the maize income. Additionally, from an environmental perspective, LF is not conducive to reducing the input of material capital such as pesticides and fertilisers.

\subsection{The Results of LF on the Use of Mechanisation}

The data in Table 5 show the correlation between LF and the farmers' purchase of machinery services. According to the estimated results of model (1), the cost of purchasing mechanised services for farmers with more plots was lower and highly significant at the $1 \%$ level, with each increase in the number of plots reducing the cost of purchasing services by an average of $10.33 \%$. Model (2) showed that the higher the proportional area of the largest three plots, the higher the cost of mechanisation, which was significant at the $1 \%$ level. Models (3) and (4) also validated this conclusion: the further the average distance of the largest three plots, the lower the cost of purchasing machinery services for farmers. Additionally, the larger the plot, the higher the input for purchasing machinery. 
Table 5. Results of LF on purchase machinery service.

\begin{tabular}{|c|c|c|c|c|}
\hline & Model (1) & Model (2) & Model (3) & Model (4) \\
\hline LF1 & $\begin{array}{c}-0.1033^{* * *} \\
(-6.072)\end{array}$ & & & \\
\hline LF2 & & $\begin{array}{c}1.1295^{* * *} \\
-5.625\end{array}$ & & \\
\hline LF3 & & & $\begin{array}{c}-0.0979 * * \\
(-2.232)\end{array}$ & \\
\hline LF4 & & & & $\begin{array}{c}0.0107^{*} \\
-1.697\end{array}$ \\
\hline Log farm size & $\begin{array}{c}0.4200^{* * * *} \\
(-0.052)\end{array}$ & $\begin{array}{c}0.3265^{* * *} \\
(-0.050)\end{array}$ & $\begin{array}{c}0.2189 * * * \\
(-0.042)\end{array}$ & $\begin{array}{c}0.2815^{* * *} \\
-6.133\end{array}$ \\
\hline Head of household characteristics & yes & yes & yes & yes \\
\hline Household characteristics & yes & yes & yes & yes \\
\hline Crop controls & yes & yes & yes & yes \\
\hline Region controls & yes & yes & yes & yes \\
\hline Constant & $\begin{array}{c}3.7600 * * * \\
-11.639\end{array}$ & $\begin{array}{c}2.7223 * * * \\
-6.517\end{array}$ & $\begin{array}{c}4.2169 * * * \\
-12.86\end{array}$ & $\begin{array}{c}4.1684^{* * *} \\
-13.186\end{array}$ \\
\hline Observations & 2635 & 2623 & 2597 & 2648 \\
\hline R-squared & 0.288 & 0.275 & 0.268 & 0.271 \\
\hline
\end{tabular}

Note: Robust $t$-statistics in parentheses; ${ }^{* * *}$ significance at $1 \%$; ${ }^{* *}$ significance at $5 \%$; ${ }^{*}$ significance at $10 \%$. For the few farmers who did not purchase machinery services, we added one and then logarithm to this variable.

The area of (mechanized) ploughed land per hour of different crops was used as an index to measure mechanical efficiency. The estimated results of the relationship between LF and mechanical efficiency are shown in Table 6. Both models (1) and (2) show that LF significantly reduced ploughed land efficiency, and this was highly significant at the $1 \%$ level. For example, in model (1), it was found that when other variables remain unchanged, each additional piece of land for farmers reduced the area of ploughed land by $0.03 \mathrm{mu}$ per hour. The results from model (3) showed some differences-specifically, the further farmers' average distance from home and higher cultivated land efficiency.

Table 6. Results of LF on ploughing efficiency.

\begin{tabular}{|c|c|c|c|c|}
\hline & Model (1) & Model (2) & Model (3) & Model (4) \\
\hline LF1 & $\begin{array}{c}-0.0259 * * * \\
(-5.103)\end{array}$ & & & \\
\hline LF2 & & $\begin{array}{c}0.2011^{* * * *} \\
(2.968)\end{array}$ & & \\
\hline LF3 & & & $\begin{array}{c}0.0313^{* *} \\
(2.059)\end{array}$ & \\
\hline LF4 & & & & $\begin{array}{c}0.0079^{* * * *} \\
(3.313)\end{array}$ \\
\hline Log farm size & $\begin{array}{c}0.1617^{* * *} \\
(-0.015)\end{array}$ & $\begin{array}{c}0.1422 * * * \\
(-0.014)\end{array}$ & $\begin{array}{c}0.1143^{* * *} \\
(-0.013)\end{array}$ & $\begin{array}{c}0.0952^{* * *} \\
(6.892)\end{array}$ \\
\hline Head of household characteristics controls & yes & yes & yes & yes \\
\hline Household characteristics controls & yes & yes & yes & yes \\
\hline Crop controls & yes & yes & yes & yes \\
\hline Region controls & yes & yes & yes & yes \\
\hline Constant & $\begin{array}{c}1.6080^{* * *} \\
(15.661)\end{array}$ & $\begin{array}{c}1.3979 * * * \\
(10.614)\end{array}$ & $\begin{array}{c}1.6328^{* * *} \\
(15.455)\end{array}$ & $\begin{array}{c}1.3662^{* * *} \\
(11.734)\end{array}$ \\
\hline Observations & 1997 & 1979 & 1974 & 1979 \\
\hline R-squared & 0.283 & 0.276 & 0.262 & 0.272 \\
\hline
\end{tabular}

Note: Robust $t$-statistics in parentheses; ${ }^{* * *}$ significance at $1 \%$; ${ }^{* *}$ significance at $5 \%$; ${ }^{*}$ significance at $10 \%$. 


\subsection{The Results of LF on Productivity}

The yield and technical efficiency were selected to measure crop productivity. Data in Tables 7 and 8 reported the impact of LF on both, respectively. Unlike the above model, the production function model was used to analyse the relationship between LF and yield. Therefore, it was necessary to add logarithmic material capital and labour cost to the control variables. From Table 7, it can be seen that the number of plots, the proportion of the largest three plots and the average plot size had no significant effect on crop yield, while the average distance to a residence significantly reduced crop yield. The yield decreased by $0.03 \mathrm{~kg}$ for every $1 \mathrm{~km}$ increase in the average distance from home. Additionally, it can be seen that the relationship between LF and yield was not significant.

Table 7. Analysis of the effect of LF on yield.

\begin{tabular}{|c|c|c|c|c|}
\hline & Model (1) & Model (2) & Model (3) & Model (4) \\
\hline LF1 & $\begin{array}{l}0.0034 \\
(0.667)\end{array}$ & & & \\
\hline LF2 & & $\begin{array}{l}0.0328 \\
(0.511)\end{array}$ & & \\
\hline LF3 & & & $\begin{array}{c}-0.0316^{* *} \\
(-2.430)\end{array}$ & \\
\hline LF4 & & & & $\begin{array}{l}-0.0020 \\
(-0.884)\end{array}$ \\
\hline $\log ($ farm size $)$ & $\begin{array}{l}0.0021 \\
(0.149)\end{array}$ & $\begin{array}{l}0.0158 \\
(1.206)\end{array}$ & $\begin{array}{l}0.0168 \\
(1.495)\end{array}$ & $\begin{array}{l}0.0160 \\
(1.317)\end{array}$ \\
\hline $\log ($ labour cost $)$ & $\begin{array}{l}0.0016 \\
(0.207)\end{array}$ & $\begin{array}{l}0.0026 \\
(0.207)\end{array}$ & $\begin{array}{l}0.0040 \\
(0.318)\end{array}$ & $\begin{array}{l}0.0030 \\
(0.238)\end{array}$ \\
\hline Log(material capita) & $\begin{array}{c}0.1792 * * * \\
(6.070)\end{array}$ & $\begin{array}{c}0.1771^{* * * *} \\
(6.010)\end{array}$ & $\begin{array}{c}0.1760^{* * *} \\
(5.926)\end{array}$ & $\begin{array}{c}0.1761^{* * *} \\
(6.005)\end{array}$ \\
\hline Head of household characteristics & yes & yes & yes & yes \\
\hline Household characteristics & yes & yes & yes & yes \\
\hline Crop controls & yes & yes & yes & yes \\
\hline Region controls & yes & yes & yes & yes \\
\hline Constant & $\begin{array}{c}5.0393 * * * \\
(24.726)\end{array}$ & $\begin{array}{c}4.9577^{* * * *} \\
(22.524)\end{array}$ & $\begin{array}{c}5.0343^{* * *} \\
(25.586)\end{array}$ & $\begin{array}{c}5.0407^{* * * *} \\
(25.163)\end{array}$ \\
\hline Observations & 2175 & 2167 & 2156 & 2190 \\
\hline R-squared & 0.374 & 0.375 & 0.366 & 0.373 \\
\hline
\end{tabular}

Note: Robust $t$-statistics in parentheses; ${ }^{* *}$ significance at $1 \%{ }^{* *}$ significance at $5 \%{ }^{*}$ significance at $10 \%$.

Table 8. Analysis of the effect of LF on technical inefficiency.

\begin{tabular}{|c|c|c|c|c|}
\hline & Model (1) & Model (2) & Model (3) & Model (4) \\
\hline \multicolumn{5}{|l|}{ Frontier } \\
\hline \multirow[t]{2}{*}{$\ln X 1$} & $0.3970 * *$ & 0.2450 & $0.4003 *$ & $0.3686^{*}$ \\
\hline & $(1.967)$ & (1.233) & $(1.946)$ & $(1.781)$ \\
\hline \multirow[t]{2}{*}{$\ln X 2$} & 0.0687 & 0.1233 & 0.0560 & 0.0726 \\
\hline & $(0.782)$ & (1.465) & $(0.636)$ & $(0.818)$ \\
\hline \multirow[t]{2}{*}{$\ln X 3$} & $0.4846^{* * *}$ & $0.5304^{* * *}$ & $0.5493^{* * *}$ & $0.5422^{* * *}$ \\
\hline & (3.035) & $(3.571)$ & (3.420) & $(3.340)$ \\
\hline \multirow[t]{2}{*}{$\ln X 4$} & 0.0475 & 0.0656 & 0.0466 & 0.0314 \\
\hline & $(0.840)$ & (1.223) & $(0.818)$ & $(0.541)$ \\
\hline \multirow[t]{2}{*}{$\ln X 1 * \ln X 1$} & 0.0017 & 0.0142 & -0.0006 & 0.0025 \\
\hline & (0.093) & (0.803) & $(-0.030)$ & $(0.131)$ \\
\hline \multirow[t]{2}{*}{$\ln X 2 * \ln X 2$} & -0.0060 & -0.0033 & -0.0032 & -0.0040 \\
\hline & $(-1.533)$ & $(-0.910)$ & $(-0.816)$ & $(-1.010)$ \\
\hline \multirow[t]{2}{*}{$\ln X 3 * \ln X 3$} & 0.0018 & -0.0082 & -0.0041 & -0.0053 \\
\hline & $(0.154)$ & $(-0.757)$ & $(-0.335)$ & $(-0.434)$ \\
\hline
\end{tabular}


Table 8. Cont.

\begin{tabular}{|c|c|c|c|c|}
\hline & Model (1) & Model (2) & Model (3) & Model (4) \\
\hline $\ln X 4^{*} \ln X 4$ & $\begin{array}{l}-0.0020 \\
(-0.480)\end{array}$ & $\begin{array}{l}-0.0013 \\
(-0.340)\end{array}$ & $\begin{array}{l}-0.0015 \\
(-0.354)\end{array}$ & $\begin{array}{l}-0.0006 \\
(-0.142)\end{array}$ \\
\hline $\ln X 1 * \ln X 2$ & $\begin{array}{l}0.0170 \\
(1.250)\end{array}$ & $\begin{array}{l}0.0040 \\
(0.310)\end{array}$ & $\begin{array}{l}0.0175 \\
(1.283)\end{array}$ & $\begin{array}{l}0.0141 \\
(1.012)\end{array}$ \\
\hline $\ln X 1 * \ln X 3$ & $\begin{array}{c}-0.0614^{* * *} \\
(-2.739)\end{array}$ & $\begin{array}{c}-0.0474^{* *} \\
(-2.247)\end{array}$ & $\begin{array}{c}-0.0574 * * \\
(-2.527)\end{array}$ & $\begin{array}{l}-0.0551 \text { ** } \\
(-2.415)\end{array}$ \\
\hline $\ln X 1 * \ln X 4$ & $\begin{array}{l}-0.0086 \\
(-1.051)\end{array}$ & $\begin{array}{l}-0.0130 * \\
(-1.676)\end{array}$ & $\begin{array}{l}-0.0089 \\
(-1.079)\end{array}$ & $\begin{array}{l}-0.0086 \\
(-1.011)\end{array}$ \\
\hline $\ln X 2 * \ln X 3$ & $\begin{array}{c}-0.0216^{* *} \\
(-2.155)\end{array}$ & $\begin{array}{c}-0.0238^{* * *} \\
(-2.578)\end{array}$ & $\begin{array}{c}-0.0240 * * \\
(-2.372)\end{array}$ & $\begin{array}{c}-0.0232 * * \\
(-2.267)\end{array}$ \\
\hline $\ln X 2 * \ln X 4$ & $\begin{array}{l}0.0057 \\
(1.435)\end{array}$ & $\begin{array}{c}0.0062 * \\
(1.718)\end{array}$ & $\begin{array}{l}0.0071^{*} \\
(1.804)\end{array}$ & $\begin{array}{c}0.0082^{* *} \\
(1.990)\end{array}$ \\
\hline $\ln X 3 * \ln X 4$ & $\begin{array}{l}0.0006 \\
(0.094)\end{array}$ & $\begin{array}{l}-0.0001 \\
(-0.023)\end{array}$ & $\begin{array}{l}-0.0010 \\
(-0.150)\end{array}$ & $\begin{array}{l}-0.0005 \\
(-0.078)\end{array}$ \\
\hline Head of household characteristics controls & yes & yes & yes & yes \\
\hline Household characteristics controls & yes & yes & yes & yes \\
\hline Crop controls & yes & yes & yes & yes \\
\hline Region controls & yes & yes & yes & yes \\
\hline \multicolumn{5}{|l|}{ Inefficiency term } \\
\hline LF1 & $\begin{array}{c}-0.0787^{* * *} \\
(-4.2404)\end{array}$ & & & \\
\hline LF2 & & $\begin{array}{l}-15.8755 \\
(-1.464)\end{array}$ & & \\
\hline LF3 & & & $\begin{array}{l}0.0153 \\
(0.409)\end{array}$ & \\
\hline LF4 & & & & $\begin{array}{l}-0.0092 * \\
(-1.702)\end{array}$ \\
\hline Log farm size & $\begin{array}{l}-0.0384 \\
(-1.039)\end{array}$ & $\begin{array}{l}-1.8754 \\
(-1.385)\end{array}$ & $\begin{array}{c}-0.1634^{* * *} \\
(-4.635)\end{array}$ & $\begin{array}{c}-0.1192 * * * * \\
(-3.327)\end{array}$ \\
\hline Usigma & $\begin{array}{c}-0.4200 * * * \\
(-6.484)\end{array}$ & $\begin{array}{c}2.0118^{* * *} \\
(3.133)\end{array}$ & $\begin{array}{c}-0.4854^{* * *} \\
(-7.897)\end{array}$ & $\begin{array}{c}-0.4733 \text { **** } \\
(-8.100)\end{array}$ \\
\hline Vsigma & $\begin{array}{c}-3.5335^{* * *} \\
(-38.966)\end{array}$ & $\begin{array}{c}-3.3879^{* * *} \\
(-44.515)\end{array}$ & $\begin{array}{c}-3.5686^{* * *} \\
(-38.940)\end{array}$ & $\begin{array}{c}-3.5692 * * * * \\
(-38.665)\end{array}$ \\
\hline Constant & $\begin{array}{c}3.1460^{* * *} \\
(3.615)\end{array}$ & $\begin{array}{c}3.2421^{* * * *} \\
(3.831)\end{array}$ & $\begin{array}{c}2.9362 * * * \\
(3.354)\end{array}$ & $\begin{array}{c}3.0536^{* * *} \\
(3.460)\end{array}$ \\
\hline Observations & 2111 & 2106 & 2091 & 2078 \\
\hline
\end{tabular}

Note: $\mathrm{z}$-statistics in parentheses; ${ }^{* *}$ significance at $1 \% ;{ }^{* *}$ significance at $5 \% ;{ }^{*}$ significance at $10 \% ; \ln X 1, \ln X 2, \ln X 3$, and $\ln X 4$ represent the natural logarithm of the material cost, labour cost, land rent, and purchase machinery service variables.

Table 8 shows the relationship between LF and technical inefficiency. Interestingly, when other variables remained unchanged, the number of land plots (model [1]) was negatively correlated with technical inefficiency. Models (2)-(4) showed that there was no significant relationship between LF and technical inefficiency. The results of the above four models revealed that the impact of LF on technical inefficiency was not robust. Using survey data from rice farmers in China, Tan et al. [27] showed that the number of land plots had a positive impact on technical efficiency, which is consistent with the results of the current study. Those who have obtained a positive relationship believe that the production of multiple plots of land can reduce risk, with the variation effect exceeding the management effect [23-26]. There is extensive heterogeneity in the different plots in China and some differences in land type, insect pests and irrigation facilities. Under the condition of controlling for the total sown area, farmers with more plots can make full use of the characteristics of different plots to allocate production factors to achieve higher technical efficiency. Based on the above analysis, it is important to be cautious about the relationship between LF and technical inefficiency. Additionally, we used the C-D production function to estimate the impact of LF on technical inefficiency (see Table A1 in Appendix A), and the 
estimated results showed little difference. The LR test showed that the model specification of the translog production function was superior to the C-D production function.

\section{Robustness}

\subsection{Valuation of Household Labour}

When analysing the relationship between LF and labour costs, the average price of hired labour in the village was used to calculate farmers' labour input costs, which implicitly assumes that all labourers have the opportunity to be hired as agricultural labourers in their communities. However, some agricultural labourers may not fully enter the non-agricultural market in rural China due to ageing or a lack of technology. They are likely to put the surplus labour into their own agricultural production, inferring that their actual labour price is lower than the market labour value. Subsequently, to validate the stability of the results, half of the average price of the non-agricultural labour market price was used to calculate the farmers' labour opportunity cost. The estimated results are shown in Table 9. When comparing the estimation results with those presented in Table 4, the estimation coefficient of LF changed very little, indicating that the impact of fragmentation on labour input was robust.

Table 9. Analysis of the effect of LF on labour cost (the labour cost of farmers' labour was calculated at one-half the prevailing wage).

\begin{tabular}{|c|c|c|c|c|}
\hline & Model (1) & Model (2) & Model (3) & Model (4) \\
\hline LF1 & $\begin{array}{c}0.0517^{* * *} \\
(5.937)\end{array}$ & & & \\
\hline LF2 & & $\begin{array}{c}-0.5274^{* * *} \\
(-5.101)\end{array}$ & & \\
\hline LF3 & & & $\begin{array}{c}0.0417 * \\
(1.847)\end{array}$ & \\
\hline LF4 & & & & $\begin{array}{l}0.0024 \\
(0.527)\end{array}$ \\
\hline Log farm size & $\begin{array}{c}-0.4134^{* * *} \\
(-15.430)\end{array}$ & $\begin{array}{c}-0.3548^{* * *} \\
(-14.881)\end{array}$ & $\begin{array}{c}-0.3127^{* * *} \\
(-14.871)\end{array}$ & $\begin{array}{c}-0.3226^{* * *} \\
(-14.389)\end{array}$ \\
\hline Head of household characteristics controls & yes & yes & yes & yes \\
\hline Household characteristics controls & yes & yes & yes & yes \\
\hline Crop controls & yes & yes & yes & yes \\
\hline Region controls & yes & yes & yes & yes \\
\hline Constant & $\begin{array}{c}3.6462^{* * *} \\
(19.367)\end{array}$ & $\begin{array}{c}4.0447^{* * *} \\
(18.172)\end{array}$ & $\begin{array}{c}3.3836^{* * * *} \\
(17.855)\end{array}$ & $\begin{array}{c}3.4301^{* * *} \\
(18.535)\end{array}$ \\
\hline Observations & 2523 & 2509 & 2489 & 2541 \\
\hline R-squared & 0.515 & 0.507 & 0.501 & 0.505 \\
\hline
\end{tabular}

Note: Robust $t$-statistics in parentheses; ${ }^{* * *}$ significance at $1 \%$; ${ }^{* *}$ significance at $5 \%$; ${ }^{*}$ significance at $10 \%$.

\subsection{Ploughing Methods}

When analysing the relationship between LF and farmland efficiency, the speed at which a farmer can plough their land was used as an index. However, the ploughing methods used by farmers may differ. For example, some use cattle to plough their land, and some use mechanical ploughing. If the ploughing method is related to LF and the scale of cultivated land, the estimated result is biased. Consequently, this complication was considered using the following means.

The data presented in Table 10 show that the farmers in the sample had a very high degree of mechanisation of ploughing rapeseed, which showed the lowest ploughing mechanisation, reaching $93.49 \%$. Wheat and soybean fields, on the other hand, essentially reached $100 \%$. Therefore, we did not have to consider any complications caused by mechanical or cattle ploughing. However, even if farmers used machinery to plough the land, the different mechanical horsepower used by different farmers may also have caused biases in the estimation results. Unfortunately, we did not investigate the horsepower of 
the machinery used by farmers when ploughing the land. Generally speaking, if a farmer purchases machinery services, the machinery horsepower will exceed the farmers' machinery horsepower. Therefore, we used whether a farmer purchased machinery services as a proxy variable of the mechanical horsepower and controlled for it in the model. The estimated results are shown in Table 11. A comparison of the data presented in Tables 8 and 11 shows that the results changed very little, further validating their robustness.

Table 10. Percentage of different crops ploughed by machine.

\begin{tabular}{cc}
\hline Crops & Ploughing (\%) \\
\hline Maize & 99.44 \\
Rice & 97.42 \\
Maize & 96.13 \\
Soybean & 99.43 \\
Rapeseed & 93.49 \\
\hline
\end{tabular}

Table 11. Analysis of the effect of LF on tilling efficiency (controlling for whether to purchase mechanical service variables).

\begin{tabular}{|c|c|c|c|c|}
\hline & Model (1) & Model (2) & Model (3) & Model (4) \\
\hline LF1 & $\begin{array}{c}-0.0242 * * * \\
(-4.800)\end{array}$ & & & \\
\hline LF2 & & $\begin{array}{c}0.1789 * * * \\
(2.634)\end{array}$ & & \\
\hline LF3 & & & $\begin{array}{c}0.0346^{* *} \\
(2.277)\end{array}$ & \\
\hline LF4 & & & & $\begin{array}{c}0.0082 * * * \\
(3.340)\end{array}$ \\
\hline Log farm size & $\begin{array}{c}0.1565^{* * *} \\
(10.809)\end{array}$ & $\begin{array}{c}0.1382 * * * \\
(9.876)\end{array}$ & $\begin{array}{c}0.1118^{* * * *} \\
(8.868)\end{array}$ & $\begin{array}{c}0.0859^{* * * *} \\
(6.350)\end{array}$ \\
\hline Purchase of mechanical services & $\begin{array}{c}0.1147^{* * *} \\
(2.756)\end{array}$ & $\begin{array}{c}0.1126^{* * *} \\
(2.647)\end{array}$ & $\begin{array}{c}0.1432 * * * \\
(3.259)\end{array}$ & $\begin{array}{c}0.1556^{* * *} \\
(3.672)\end{array}$ \\
\hline Head of household characteristics & yes & yes & yes & yes \\
\hline Family characteristics & yes & yes & yes & yes \\
\hline Crop controls & yes & yes & yes & yes \\
\hline Region controls & yes & yes & yes & yes \\
\hline Constant & $\begin{array}{c}1.6080 * * * \\
(15.661)\end{array}$ & $\begin{array}{c}1.3979 * * * \\
(10.614)\end{array}$ & $\begin{array}{c}1.6328^{* * *} \\
(15.455)\end{array}$ & $\begin{array}{c}1.4982 * * * \\
(13.633)\end{array}$ \\
\hline Observations & 1997 & 1979 & 1974 & 1996 \\
\hline R-squared & 0.283 & 0.276 & 0.262 & 0.266 \\
\hline
\end{tabular}

Note: Robust $t$-statistics in parentheses; ${ }^{* * *}$ significance at $1 \%$; ${ }^{* *}$ significance at $5 \%$; ${ }^{*}$ significance at $10 \%$.

\subsection{Land Fragmentation Indicator Check}

The LF indicators of LF2 and LF3 were based on the three largest plots. Sometimes the farmers had less than three plots, and their actual plot number may have been between 1 and 21. To check the robustness of the estimated results, we selected samples with more than three plots for regression. From Table 12, it can be seen that except for the effect of LF2 on ploughing efficiency and the effect of LF3 on ploughing efficiency and technical inefficiency, the other estimates underwent little change, further validating the robustness of the results. 
Table 12. Robust check of LF2 and LF3 on farm performance.

\begin{tabular}{|c|c|c|c|c|c|c|}
\hline & Material Cost & Labour Cost & $\begin{array}{c}\text { Machinery } \\
\text { Service }\end{array}$ & $\begin{array}{l}\text { Ploughing } \\
\text { Efficiency }\end{array}$ & Yield & $\begin{array}{l}\text { Technical } \\
\text { Inefficiency }\end{array}$ \\
\hline \multicolumn{7}{|c|}{ Panel A: Relationship between LF2 and farm performance. } \\
\hline LF2 & $\begin{array}{l}-0.1369 * \\
(-1.803)\end{array}$ & $\begin{array}{c}-0.4705^{* * *} \\
(-3.191)\end{array}$ & $\begin{array}{c}1.4493^{* * *} \\
(4.796)\end{array}$ & $\begin{array}{l}0.1272 \\
(1.201)\end{array}$ & $\begin{array}{l}0.0413 \\
(0.471)\end{array}$ & $\begin{array}{c}-1.5010^{* * *} \\
(-8.635)\end{array}$ \\
\hline Log farm size & $\begin{array}{c}-0.0748 * * * \\
(-3.988)\end{array}$ & $\begin{array}{c}-0.4361^{* * *} \\
(-10.924)\end{array}$ & $\begin{array}{c}0.4539 * * * \\
(5.012)\end{array}$ & $\begin{array}{l}0.1914^{* * *} \\
(7.260)\end{array}$ & $\begin{array}{l}0.0161 \\
(0.873)\end{array}$ & $\begin{array}{c}-0.2356^{* * *} \\
(-5.766)\end{array}$ \\
\hline \multicolumn{7}{|c|}{ Panel B: Relationship between LF3 and farm performance. } \\
\hline LF3 & $\begin{array}{c}-0.0405^{* *} \\
(-2.342)\end{array}$ & $\begin{array}{l}0.0262 * \\
-1.813\end{array}$ & $\begin{array}{c}-0.0082 * * \\
(-2.139)\end{array}$ & $\begin{array}{l}-0.0011 \\
(-0.049)\end{array}$ & $\begin{array}{l}-0.0256^{*} \\
(-1.949)\end{array}$ & $\begin{array}{l}-0.0231 \\
(-0.331)\end{array}$ \\
\hline Log farm size & $\begin{array}{c}-0.0660 * * * \\
(-3.712)\end{array}$ & $\begin{array}{l}-0.3970 * * * \\
(-10.959)\end{array}$ & $\begin{array}{c}0.3037^{* * *} \\
(3.751)\end{array}$ & $\begin{array}{c}0.1760^{* * *} \\
(7.333)\end{array}$ & $\begin{array}{l}0.0145 \\
(0.796)\end{array}$ & $\begin{array}{c}-0.4873^{* * * *} \\
(-12.781)\end{array}$ \\
\hline
\end{tabular}

Note: Robust $t$-statistics in parentheses; ${ }^{* * *}$ significance at $1 \% ;{ }^{* *}$ significance at $5 \%{ }^{*}$ significance at $10 \%$; the sample only retained farmers with more than three plots, and the control variables were the same as before (they are omitted here).

\subsection{Outlier Value check}

Many outliers were present in the farmers' survey data. For example, the yield per mu ranged from $2.0 \mathrm{~kg}$ to $1000 \mathrm{~kg}$ per mu. Although we took into account the natural logarithm of the relevant variables in the model, we were concerned the results would be biased due to outlier values. Therefore, we checked the robustness in two ways, which involved dropping and winsorising $5 \%$ of samples for dependent variables on both sides, respectively. Tables 13 and 14 show the impact of LF on labour cost and yield. Compared with Tables 4 and 7 , the estimated results revealed little change, indicating that the previous results are robust.

Table 13. Robustness test of LF on labour cost.

\begin{tabular}{cccc}
\hline Model (1) & Model (2) & Model (3) & Model (4) \\
\hline \multicolumn{2}{c}{ Panel A: Five percent of the samples were dropped } & from the dependent variable on both sides. \\
\hline $0.0381^{* * *}$ & $-0.4629^{* * *}$ & 0.0225 & 0.0036 \\
$(4.723)$ & $(-4.888)$ & $(1.097)$ & $(0.874)$ \\
\hline \multicolumn{2}{c}{ Panel B: Five percent of the samples were } & winsorised at $5 \%$ on both sides. \\
\hline $0.0515^{* * *}$ & $-0.5394^{* * *}$ & $0.0392^{*}$ & 0.0017 \\
$(6.220)$ & $(-5.527)$ & $(1.840)$ & $(0.438)$ \\
\hline
\end{tabular}

Note: Panel A and pane B represents two methods used to check the outliers of the dependent variables; the control variables in the above model are the same as those in Table 4 (they are omitted here); models (1)-(4) represent the regression of LF1-LF4 on labour cost, respectively; ${ }^{* * *}$ significance at $1 \%$; ${ }^{* *}$ significance at $5 \%$; * significance at $10 \%$.

Table 14. Robustness test of LF on yield.

\begin{tabular}{cccc}
\hline Model (1) & Model (2) & Model (3) & Model (4) \\
\hline Panel A: Five percent of the samples were dropped & from the dependent variable on both sides. \\
\hline 0.0034 & 0.0328 & $-0.0316^{* *}$ & -0.0020 \\
$(0.667)$ & $(0.511)$ & $(-2.430)$ & $(-0.884)$ \\
\hline \multicolumn{4}{c}{ Panel B: Five percent of the samples were winsorised on both sides. } \\
\hline 0.0028 & 0.0266 & $-0.0232 * *$ & -0.0019 \\
$(0.740)$ & $(0.543)$ & $(-2.149)$ & $(-1.231)$ \\
\hline
\end{tabular}

Note: Panel A and pane B represent two methods used to check the outliers of the dependent variables; the control variables in the above model are the same as those in Table 7 (they are omitted here); models (1)-(4) represent the regression of LF1-LF4 on yield, respectively; ${ }^{* * *}$ significance at $1 \%$; ${ }^{* *}$ significance at $5 \%$; ${ }^{*}$ significance at $10 \%$. 


\section{Conclusions}

Based on the unique crop-level survey data from ten provinces in China, the current study investigated the correlation between four indicators representing land fragmentation (LF) and six indicators representing farm performance. The OLS model was used to empirically analyse the relationship between LF and farm performance. To the authors knowledge, this study is the first to investigate the relationship between LF and multiple production indicators and the first to comprehensively compare and analyse the "good" and "bad" effects of LF on farm performance. The results revealed that while controlling for other variables, LF increased the input of farmers' material cost and increased the cost of labour input. Due to the fragmented land in China, it is difficult for farmers to implement large-scale production. Some new equipment and new technologies that save labour and material costs are also challenging to implement in this context. For example, drone spraying can save pesticides and labour and improve insecticidal efficiency. However, the large-scale production of one crop is difficult to implement in areas in China where the land is severely fragmented. In terms of mechanisation, the fragmentation of land was found to reduce the purchase of machinery services by farmers. Accordingly, the larger the scale of the land, the easier it is for farmers to purchase supporting mechanical services from the market. For small-scale land, it was found that farmers tended to use their own machinery or their own labour for agricultural production. Additionally, it was identified that the more severe the LF, the lower the efficiency of mechanical ploughing. It was also found that LF did not affect crop yields in terms of productivity but had a positive effect on technical efficiency, although these results were not sufficiently robust.

The current study found that LF correlated differently with farm performance and, overall, the adverse effects dominated. These results confirm that incentives to encourage land-leasing and consolidation are justified to improve farm performance from a policy perspective. Simultaneously, in areas with severe LF, the development of small agricultural machinery should be encouraged to meet the needs of small or impoverished farmers. As China's economy develops, LF to large-scale production will be the trend dominating land-use transitions. However, integrating land should be undertaken cautiously. Largescale production was negatively correlated with some farm performance, such as technical efficiency. Therefore, increasing the scale of land should improve farmers' management level and prevent the reduction of technical efficiency.

Author Contributions: S.W. conceived and designed the structure of this study and cleaned the data, ran models, and wrote part of the paper. D.L. wrote the introduction and literature review. T.L. and C.L. participated in the paper discussion and revision. All authors have read and agreed to the published version of the manuscript.

Funding: This research was funded by the Youth Program of National Natural Science Foundation of China (Grant No. 72003194, 41901216), the China Agriculture Research System of MOF and MARA, the Youth Program of National Social Science Fund of China (Grant No. 18CJY032), the Program of Comprehensive Survey on Rural Revitalization and China Rural Survey Database funded by Chinese Academy of Social Sciences (Grant No. GQDC2020017), the Bagui Scholars Program of Guangxi Zhuang Autonomous Region, and the Program of Science and Technology Plan of Guangxi Zhuang Autonomous Region (Grant No. AD19110158).

Institutional Review Board Statement: Not applicable.

Informed Consent Statement: Not applicable.

Data Availability Statement: As the data gathered came from field surveys conducted by the research team, it is not publicly available. The data used in this paper are available upon request from the corresponding author.

Conflicts of Interest: The authors declare no conflict of interest. 


\section{Appendix A}

Table A1. Analysis of the effect of LF on technical inefficiency using the C-D production function.

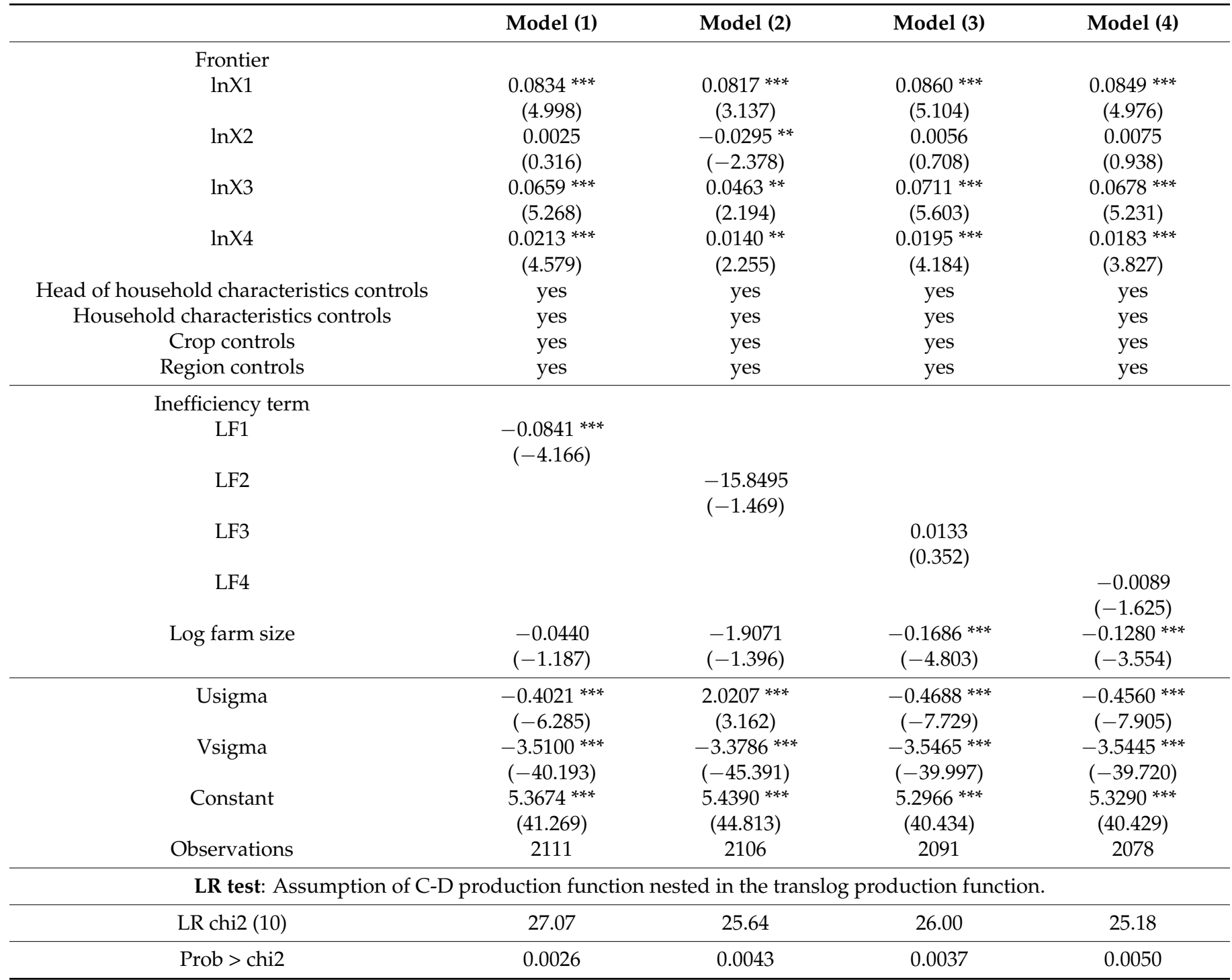

Note: $\mathrm{z}$-statistics in parentheses; ${ }^{* * *}$ significance at $1 \% ;{ }^{* *}$ significance at $5 \% ;{ }^{*}$ significance at $10 \% ; \ln X 1, \ln X 2, \ln X 3$, and $\ln X 4$ represent the natural logarithm of the material cost, labour cost, land rent, and purchase machinery service variables.

\section{References}

1. Huang, J.; Yang, G. Understanding recent challenges and new food policy in China. Glob. Food Secur. 2017, 12, 119-126. [CrossRef]

2. Gong, B. Agricultural reforms and production in China: Changes in provincial production function and productivity in 1978-2015. J. Dev. Econ. 2018, 132, 18-31. [CrossRef]

3. Zhao, Y. Leaving the Countryside: Rural-to-Urban Migration Decisions in China. Am. Econ. Rev. 1999, 89, 281-286. [CrossRef]

4. Long, H. Land consolidation: An indispensable way of spatial restructuring in rural China. J. Geogr. Sci. 2014, 24, 211-225. [CrossRef]

5. Xu, D.; Yong, Z.; Deng, X.; Zhuang, L.; Qing, C. Rural-Urban Migration and its Effect on Land Transfer in Rural China. Land 2020, 9, 81. [CrossRef]

6. Huang, J.; Ding, J. Institutional innovation and policy support to facilitate small-scale farming transformation in China. Agric. Econ. 2016, 47, 227-237. [CrossRef]

7. Lin, J.Y. Rural factors markets in China after the household responsibility system reform. In Chinese Economic Policy: Economic reform at Midstream; Reynolds, B., Ed.; Paragon House: New York, NY, USA, 1989; pp. 487-509.

8. Wang, H.; Tong, J.; Su, F.; Wei, G.; Ran, T. To reallocate or not: Reconsidering the dilemma in China's agricultural land tenure policy. Land Use Policy 2011, 28, 805-814. [CrossRef] 
9. Manjunatha, A.; Anik, A.R.; Speelman, S.; Nuppenau, E. Impact of land fragmentation, farm size, land ownership and crop diversity on profit and efficiency of irrigated farms in India. Land Use Policy 2013, 31, 397-405. [CrossRef]

10. Wang, X.; Yamauchi, F.; Huang, J.; Rozelle, S. What constrains mechanization in Chinese agriculture? Role of farm size and fragmentation. China Econ. Rev. 2020, 62, 101221. [CrossRef]

11. Deininger, K.; Savastano, S.; Carletto, C. Land fragmentation, cropland abandonment, and land market operation in Albania. World Dev. 2012, 40, 2108-2122. [CrossRef]

12. Kawasaki, K. The costs and benefits of land fragmentation of rice farms in Japan. Aust. J. Agric. Resour. Econ. 2010, 54, 509-526. [CrossRef]

13. Deininger, K.; Monchuk, D.; Nagarajan, H.K.; Singh, S.K. Does Land Fragmentation Increase the Cost of Cultivation? Evidence from India. J. Dev. Stud. 2016, 53, 82-98. [CrossRef]

14. Yan, X.; Bauer, S.; Huo, X. Farm size, land reallocation, and labour migration in rural China. Popul. Space Place 2014, 20, 303-315. [CrossRef]

15. Lu, H.; Xie, H.; Yao, G. Impact of land fragmentation on marginal productivity of agricultural labor and non-agricultural labor supply: A case study of Jiangsu, China. Habitat Int. 2019, 83, 65-72. [CrossRef]

16. Van den Berg, M.M.; Hengsdijk, H.; Wolf, J.; Van Ittersum, M.K.; Wang, G.; Roetter, R.P. The impact of increasing farm size and mechanization on rural income and rice production in Zhejiang province, China. Agric. Syst. 2007, 94, 841-850. [CrossRef]

17. Rahman, S.; Rahman, M. Impact of land fragmentation and resource ownership on productivity and efficiency: The case of rice producers in Bangladesh. Land Use Policy 2009, 26, 95-103. [CrossRef]

18. Tran, T.Q.; Van Vu, H. Land fragmentation and household income: First evidence from rural Vietnam. Land Use Policy 2019, 89, 104247. [CrossRef]

19. Kan, K. Creating land markets for rural revitalization: Land transfer, property rights and gentrification in China. J. Rural. Stud. 2021, 81, 68-77. [CrossRef]

20. Li, Y.; Wu, W.; Liu, Y. Land consolidation for rural sustainability in China: Practical reflections and policy implications. Land Use Policy 2018, 74, 137-141. [CrossRef]

21. Fenoaltea, S. Risk, transaction costs, and the origin of medieval agriculture. Explor. Econ. Hist. 1976, 13, 129-151. [CrossRef]

22. Knippenberg, E.; Jolliffe, D.; Hoddinott, J. Land Fragmentation and Food Insecurity in Ethiopia. Am. J. Agric. Econ. 2020, 102, 1557-1577. [CrossRef]

23. Bentley, J.W. Economic and ecological approaches to land fragmentation: In defense of a much-maligned phenomenon. Annu. Rev. Anthropol. 1987, 16,31-67. [CrossRef]

24. Ntihinyurwa, P.D.; de Vries, W.T. Farmland fragmentation, farmland consolidation, and food security: Relationships, research lapses and future perspectives. Land 2021, 10, 129. [CrossRef]

25. Benin, S.; Smale, M.; Pender, J.; Gebremedhin, B.; Ehui, S. The economic determinants of cereal crop diversity on farms in the Ethiopian highlands. Agric. Econ. 2004, 31, 197-208. [CrossRef]

26. Ntihinyurwa, P.D.; de Vries, W.T.; Chigbu, U.E.; Dukwiyimpuhwe, P.A. The positive impacts of farmland fragmentation in Rwanda. Land Use Policy 2019, 81, 565-581. [CrossRef]

27. Tan, S.; Heerink, N.; Kuyvenhoven, A.; Qu, F. Impact of land fragmentation on rice producers' technical efficiency in South-East China. NJAS Wagening. J. Life Sci. 2010, 57, 117-123. [CrossRef]

28. Latruffe, L.; Piet, L. Does land fragmentation affect farm performance? A case study from Brittany, France. Agric. Syst. 2014, 129, 68-80. [CrossRef]

29. He, M. An Analysis of the Impact of Land Fragmentation on Agricultural Production Cost: Evidence from Farmers in Gansu Province, P.R. China. s.n. 2014. Available online: http:/ / edepot.wur.nl/313215 (accessed on 5 April 2021).

30. Wan, G.H.; Cheng, E. Effects of land fragmentation and returns to scale in the Chinese farming sector. Appl. Econ. 2001, 33, 183-194. [CrossRef]

31. Lu, H.; Xie, H.; He, Y.; Wu, Z.; Zhang, X. Assessing the impacts of land fragmentation and plot size on yields and costs: A translog production model and cost function approach. Agric. Syst. 2018, 161, 81-88. [CrossRef]

32. Binns, B.O. The Consolidation of Fragmented Agricultural Holdings; Food and Agriculture Organization, United Nations: Washington, DC, USA, 1950.

33. Jha, R.; Nagarajan, H.K.; Prasanna, S. Land Fragmentation and Its Implications for Productivity: Evidence from Southern India; Australia South Asia Research Centre (ASARC) Working Paper 2005/01; ASARC: Canberra, Australia, 2005.

34. Pavel, C.; Miroslava, R.; Guri, F.; Zhllima, E.; Shahu, E. The impact of crop rotation and land fragmentation on farm productivity in Albania. Stud. Agric. Econ. 2018, 120, 116-125. [CrossRef]

35. Dovring, F.; Dovring, K. Land and Labor in Europe in 1900-1950, 2nd ed.; Springer: The Hague, The Netherlands, $1960 ;$ pp. 42-51.

36. Blare, B.; Hazell, P.; Place, F.; John, Q. The economics of farm fragmentation: Evidence from Ghana and Rwanda. World Bank Econ. Rev. 1992, 6, 233-254. [CrossRef]

37. Looga, J.; Jürgenson, E.; Sikk, K.; Matveev, E.; Maasikamäe, S. Land fragmentation and other determinants of agricultural farm productivity: The case of Estonia. Land Use Policy 2018, 79, 285-292. [CrossRef]

38. Wang, Y.; Li, X.; Lu, D.; Yan, J. Evaluating the impact of land fragmentation on the cost of agricultural operation in the southwest mountainous areas of China. Land Use Policy 2020, 99, 105099. [CrossRef] 
39. Jabarin, A.S.; Epplin, F.M. Impacts of land fragmentation on the cost of producing wheat in the rain-fed region of northern Jordan. Agric. Econ. 1994, 11, 191-196. [CrossRef]

40. Austin, O.C.; Ulunma, A.C.; Sulaiman, J. Exploring the Link between Land Fragmentation and Agricultural Productivity. Int. J. Stat. Appl. 2012, 2, 30-34. [CrossRef]

41. Jia, L.; Petrick, M. How does land fragmentation affect off-farm labor supply: Panel data evidence from China. Agric. Econ. 2014, 45, 369-380. [CrossRef]

42. Alemu, G.T.; Ayele, Z.B.; Berhanu, A.A. Effects of Land Fragmentation on Productivity in Northwestern Ethiopia. Adv. Agric. 2017, 2017, 1-9. [CrossRef]

43. Tan, S. Land Fragmentation and Rice Production: A Case Study of Small Farms in Jiangxi Province, P.R. China. Ph.D. Thesis, Wageningen University and Research, Wageningen, The Netherlands, 2005.

44. Kadigi, R.M.; Kashaigili, J.J.; Sirima, A.; Kamau, F.; Sikira, A.; Mbungu, W. Land fragmentation, agricultural productivity and implications for agricultural investments in the Southern Agricultural Growth Corridor of Tanzania (SAGCOT) region. Tanzan. J. Dev. Agric. Econ. 2017, 9, 26-36.

45. Veljanoska, S. Can land fragmentation reduce the exposure of rural households to weather variability? Ecol. Econ. 2018, 154, 42-51. [CrossRef]

46. Wang, H.J.; Schmidt, P. One-step and two-step estimation of the effects of exogenous variables on technical efficiency levels. J. Product. Anal. 2002, 1, 129-144. [CrossRef]

47. Belotti, F.; Daidone, S.; Ilardi, G.; Atella, V. Stochastic Frontier Analysis using Stata. Stata J. Promot. Commun. Stat. 2013, 13, 719-758. [CrossRef]

48. Deolalikar, A.B. The Inverse Relationship between Productivity and Farm Size: A Test Using Regional Data from India. Am. J. Agric. Econ. 1981, 63, 275-279. [CrossRef]

49. Gautam, M.; Ahmed, M. Too Small to Be Beautiful? The Farm Size and Productivity Relationship in Bangladesh. Food Policy 2018, 84, 165-175. [CrossRef]

50. Wineman, A.; Jayne, T.S. Factor Market Activity and the Inverse Farm Size-Productivity Relationship in Tanzania. J. Dev. Stud. 2020, 57, 443-464. [CrossRef]

51. Helfand, S.M.; Levine, E.S. Farm Size and the Determinants of Productive Efficiency in the Brazilian Center-West. Agric. Econ. 2004, 31, 241-249. [CrossRef]

52. Carletto, C.; Gourlay, S.; Winters, P. From guesstimates to GPStimates: Land area measurement and implications for agricultural analysis. J. Afr. Econ. 2015, 24, 593-628. [CrossRef]

53. Desiere, S.; Jolliffe, D. Land productivity and plot size: Is measurement error driving the inverse relationship? J. Dev. Econ. 2018, 130, 84-98. [CrossRef] 